\title{
Magnetisk klimaforskning - påvirker Jordens magnetfelt klimaet?
}

Af Mads Faurschou Knudsen, Geologisk Institut på Aarhus Universitet og Peter Riisager, GEUS

En simpel sammenligning imellem klimadata fra drypstenshuler og en ny rekonstruktion af Jordens tidligere magnetfelt indikerer, at Jordens magnetfelt har påvirket klimaet igennem de sidste fem tusinde år.

Gennem årene er det fra tid til anden blevet foreslået, at Jordens magnetfelt påvirker klimaet, dog uden at nogen har været i stand til at påvise denne sammenhæng på en overbevisende måde. Spørgsmålet har ikke drejet sig om "i hvor høj grad” Jordens magnetfelt påvirker klimaet, men mere grundlæggende "om" der overhovedet er en forbindelse mellem de to parametre.

\section{Kosmisk stråling og klima}

Spekulationer om en forbindelse mellem Jordens magnetfelt og klimaet er ikke taget ud af den blå luft, idet nogle fysiske modeller faktisk forudser, at der kan være en sådan sammenhæng. For eksempel er der den postulerede forbindelse mellem kosmisk stråling og klima med følgende teoretiske årsagssammenhæng: Kosmisk stråling ioniserer troposfæren, og denne ionisering er helt essentiel for dannelsen af stabile skykondensationskerner, som i sig selv er nødvendig for dannelsen af egentlige skydråber - og i sidste ende skyer. Mængden af lave skyer i troposfæren er meget vigtig for Jordens strålingsbalance, og da de lave skyer samlet set har en afkølende effekt, vil en øget global mængde af lave skyer medføre en afkøling af Jorden.

Solens magnetfelt, som er tæt forbundet med soludstrålingen, afskærmer vores planetsystem mod de kosmiske partikler, således at når solens magnetfelt er stærkt, er der færre kosmiske partikler, der har tilstrækkelig energi til at trænge helt ind til Jordens atmosfære. Omvendt, hvis solens magnetfelt er svagt, vil flere kosmiske partikler trænge ind $i$ atmosfæren.

Det basale i den postulerede forbindelse imellem kosmisk stråling og klima er, at Solens variationer kan ændre det globale skydække og dermed have en relativt stor indflydelse på klimaet. De mikrofysiske processer, der er involveret, er dog ikke

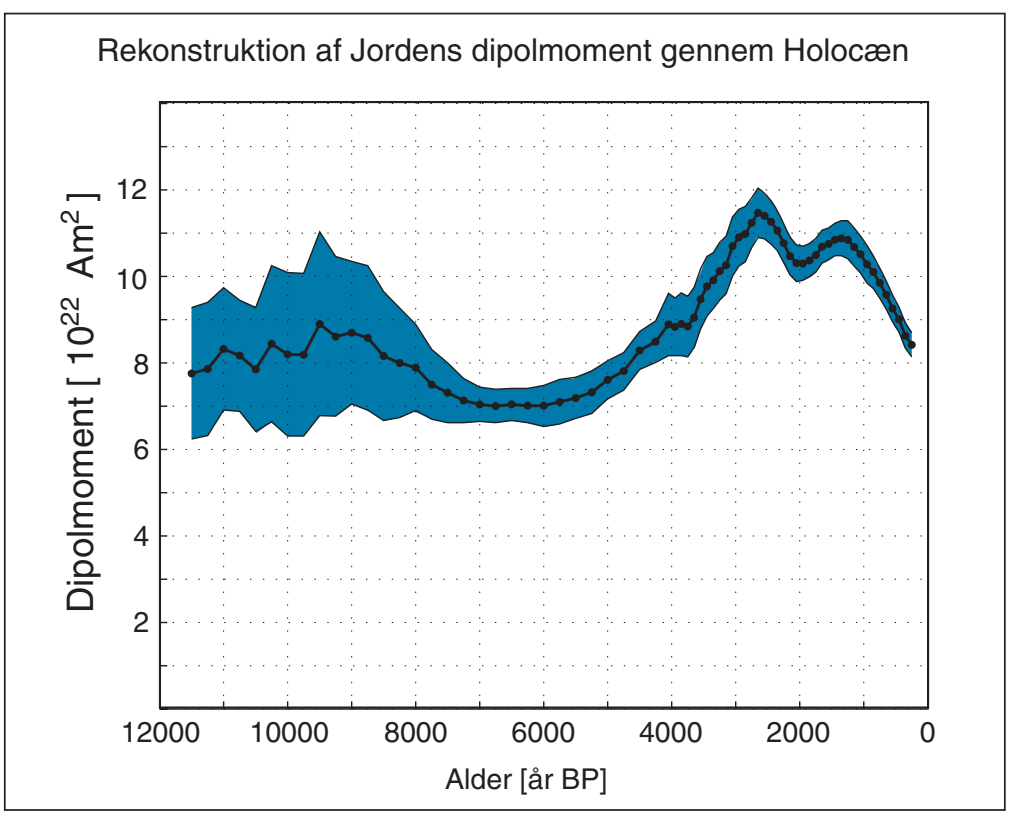

Rekonstruktion af Jordens dipolmoment gennem den holoccene periode, dvs. de sidste ca. 11.700 år. Som det kan ses af figuren, er usikkerheden på bestemmelsen af dipolmomentet (blå zone) betydeligt højere $i$ den tidlige del af Holocan, hvilket skyldes, at der er betydeligt farre palcomagnetiske observationer fra denne periode. (Grafik: Earth and Planetary Science Letters 272, 319-329)

forstået til bunds, og det er derfor meget vanskeligt at kvantificere, i hvor høj grad denne effekt påvirker klimasystemet. Følgelig er den kosmiske forbindelse mellem solen og klimaet ikke inkluderet i de ellers meget avancerede klima-modeller, og derfor repræsenterer den et af de åbne spørgsmål i forståelsen af Jordens klimasystem. Faktisk har den kosmiske forbindelse udviklet sig til et af de væsentligste stridspunkter blandt klimaforskerne.

Det, der for os er en interessant detalje ved teorien om kosmisk stråling og klima, er, at det ikke kun er Solens magnetfelt, der afskærmer Jorden fra bombardementet af kosmiske partikler fra rummet. Jordens eget magnetfelt beskytter også vores planet mod de kosmiske partikler. Hvis kosmiske partikler påvirker skydannelsen og derigennem Jordens klima, så er det nærliggende at tro, at Jordens eget magnetfelt også har et potentiale for at influere klimaet.

Disse overvejelser var grunden til, at vi gav os i kast med at undersøge denne mulige sammenhæng mellem to parametre, man normalt ikke forbinder med hinanden.
Uden at gå nærmere i detaljer er der faktisk også andre teoretiske sammenhænge, hvorigennem Jordens magnetfelt kan have indflydelse på klimaet. Vores studium er dog på ingen måde teoretisk anlagt. Måden, som vi har valgt at undersøge den mulige forbindelse imellem magnetfelt og klima, er derimod ekstremt pragmatisk - vi har simpelthen kigget i de geologiske arkiver.

\section{Jordens tidligere magnetfelt}

Der er en hel videnskab, der dedikerer sig til at bestemme Jordens tidligere magnetfelt, nemlig palæomagnetisme. Palæomagnetisme er baseret på det faktum, at stort set alle bjergarter indeholder magnetiske korn, der ved bjergartens dannelsestidspunkt optager og gemmer en magnetisering bestemt af det omgivende magnetfelt. Ved at studere magnetiseringen af geologiske prøver kan man derfor bestemme Jordens tidligere magnetfelt. Afhængigt af de magnetiske mineralers kornstørrelse og sammensætning kan geologiske prøver i princippet gemme deres oprindelige magnetisering i milliarder af år. I praksis slettes dele af den oprindelige 
magnetisering dog, når bjergarter udsættes for forvitring, varme og kemiske omdannelser.

En helt central del af palæomagnetismen beskæftiger sig med metoder til at indsamle prøver og dechifrere deres fossile magnetisering. Man kan sige, at palæomagnetikere forsøger at læse og forstå det naturlige arkiv over Jordens tidligere magnetfelt, som er gemt i geologiske prøver. Ved at anvende avancerede teknikker på vulkanske bjergarter og brændte arkæologiske objekter, såsom potteskår og teglprodukter, er det muligt at bestemme styrken af Jordens tidligere magnetfelt.

Sammen med kollegaer har vi indsamlet og kompileret alle publicerede palæomagnetiske undersøgelser af Jordens magnetfeltsstyrke bestemt ud fra bjergarter og arkæologiske objekter, der er yngre end 50.000 år.

Alle data blev katalogiseret og placeret $i$ en database (GEOMAGIA50), der nu er offentligt tilgængelig via en web-browser ( $p a ̊$ adressen: http://geomagia.ucsd.edu/).

Næste skridt var at bruge GEOMAGIA til at bestemme den dipolmomentskurve, der bedst stemmer overens med de kompilerede data. Som videnskab nu engang er, har andre forskere naturligvis tidligere lavet andre kurver over dipolmomentet, men af forskellige årsager er vi overbeviste om, at vores dipolmomentskurve aktuelt repræsenterer det bedste bud på variationen i dipolmomentet gennem den holocæne periode (dvs. de sidste $\sim 11.700$ år). (Den meget interesserede læser kan se nærmere i den videnskabelige artikel, der er henvist til i slutningen af denne artikel).

Vores bestemmelse af Jordens magnetiske dipolmoment gennem Holocæn (figuren på foregående side) er baseret på en gruppering af data $i$ tidsvinduer på 500 år og 1.000 år for at minimere effekten fra dateringsfejl, som kan være signifikante, samt højereordens komponenter af Jordens magnetfelt, der ikke kan beskrives med et dipolfelt. Det er værd at bide mærke i, at dipolmomentet faktisk har været meget dynamisk igennem hele Holocæn. Der har altså været tilstræk-
Stalagmit fra en drypstenshule i Kina før "foeldning" (højre billede). Stalagmitten saves igennem på langs, og det er herefter muligt at udtage mikroskopiske prøver fra stalagmittens loengdeakse. Prøven analyseres efterfølgende $i$ et massespektrometer for at bestemme forholdet mellem de lette og tunge iltisotoper $\left(\delta^{18} O\right)$. Stalagmitten og de enkelte prøvers alder bestemmes vha. den meget pracise Uran-Thorium-metode. (Grafik: Earth and Planetary Science Letters 266, 221-232.)

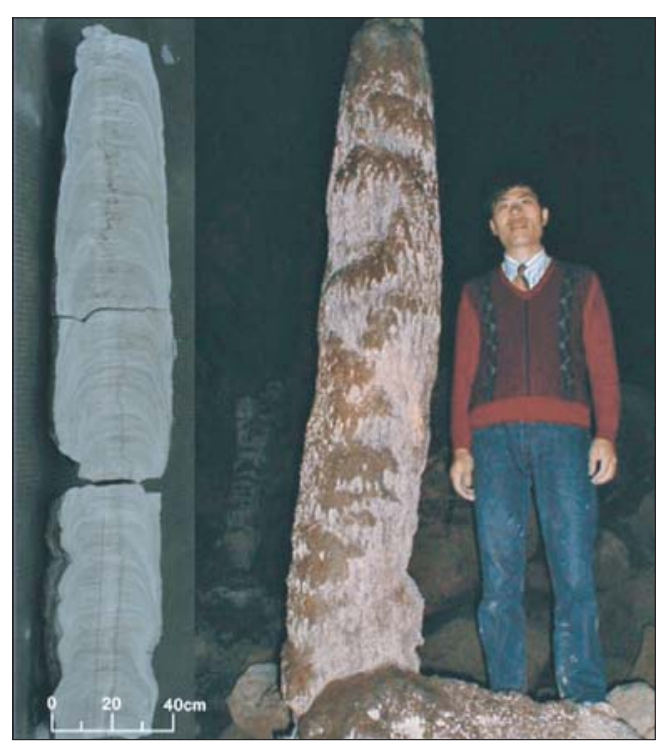

kelig variation i Jordens magnetfelt gennem Holocæn til, at det kan have skubbet lidt til klimasystemet, forudsat naturligvis at Jordens magnetfelt rent faktisk påvirker klimaet

\section{Tropisk nedbør gennem Holocæn}

Hvis der er en sammenhæng mellem Jordens magnetfelt og klimaet, kan man ikke nødvendigvis forvente at kunne finde sporene af denne forbindelse alle steder på planeten. På grund af dipolfeltets geometri vil afskærmningen være stærkt afhængig af breddegraden, således at afskærmningen er maksimal ved ækvator, mens den er forsvindende lille ved de geografiske poler.

I vores bestræbelser på at undersøge sammenhængen mellem magnetfeltet og klimaet opstillede vi derfor en række kriterier for at afgøre, hvor der var størst sandsynlighed for at finde spor af denne forbindelse.

Det første kriterium for udvælgelse af relevante klimadata var netop, at de skulle stamme fra områder tæt ved ækvator pga. magnetfeltets geometri.

Et andet kriterium var, at de skulle stamme fra områder med stort potentiale for skydannelse, og områder hvor satellit-observationer har demonstreret en god korrelation mellem mængden af lave skyer og kosmiske partikler over de sidste årtier. Tropiske egne beliggende tæt ved havet er de områder, der bedst opfylder dette kriterium.

Et tredje kriterium var, at de udvalgte klimadata skulle afspejle processer i atmosfæren, fx nedbørsrelaterede processer, fordi det er her, den direkte påvirkning fra de kosmiske partikler finder sted. Sidst, men ikke mindst var det nødvendigt at udvælge klimadata, der er understøttet af en pålidelig aldersmodel, og som er karakteriseret ved høj opløselighed gennem et længere tidsinterval i Holocæn.

De klimadata, der bedst opfylder ovennævnte kriterier, er de fremragende $\delta^{18} \mathrm{O}$ data fra stalagmitter i tropiske egne, der er publiceret inden for de sidste $\sim 5$ år. Stalagmitter er sekundære kalkaflejringer, der kan vokse over tusinder af år i drypstenshuler (figuren ovenfor). Ved at indsamle mikroskopiske prøver fra et tværsnit af en stalagmit kan man være heldig at få en kontinuerlig tidsserie af klimadata. Specielt interessant er forholdet mellem de lette og 
Jordens dipolmoment (sort kurve) med tilhørende usikkerhedsestimat (grå zone) samt $\delta^{18} \mathrm{O}$-data fra Dongge Cave i Kina (blà kurve). De pågceldende $\delta^{18} O$ data afspejler cendringer i moengden af nedbør i området. Jordens dipolmoment (M) og cendringer i nedbøren $\left(\delta^{18} O\right)$ er bestemt ved at gruppere data i A) tidsintervaller på 500 år i perioden 0-4000 $\mathrm{BP}$ og $i$ intervaller på 1000 år $i$ den forudgående periode samt $i$ B) tidsintervaller på 100 år gennem hele perioden. Den orange kurve beskriver cendringer $i$ solindstrålingen (insolation) gennem Holoccen som funktion af cendringer $i$ Jordens baneparameter. Den gode korrelation over de sidste ca. fem

tusinde år indikerer kraftigt, at Jordens magnetfelt har påvirket klimaet i området. Dette stemmer overens med nye modelberegninger, der viser, at cendringer $i$ Jordens dipolmoment har påvirket ioniseringen i troposfceren $i$ visse cekvatoriale områder gennem den holocane periode (Usoskin et al., 2008). Studiet af sammenhoengen mellem dipolmomentet og monsun-nedbøren i Kina leverer faktisk de første empiriske observationer, der direkte kan kcedes sammen med disse nye modelberegninger. (Grafik: Forfatterne) tunge iltisotoper $\left(\delta^{18} \mathrm{O}\right)$ i stalagmitterne, der hovedsageligt afspejler tidligere tiders nedbørsmængder. Dette skyldes den såkaldte "amount effect", der beskriver, hvorledes $\delta^{18} \mathrm{O}$-signalet bliver mere negativt, jo mere det har regnet, fordi den tunge ${ }^{18} \mathrm{O}$-isotop "regner ud" før den lettere ${ }^{16} \mathrm{O}$-isotop.

Undersøgelser af stalagmitter fra drypstenhuler har over de senere år frembragt en række nye klimadatasæt af meget høj opløselighed, og ud fra disse data er det således muligt at rekonstruere monsun-nedbøren gennem tusinder af år i visse områder. Desværre er det kun få stalagmitter, der har “optaget" nedbørsmængden over længere perioder, og der findes således kun meget få kontinuerlige datasæt, der dækker hele den mellemistid, vi nu befinder os i. To af de mest velegnede stalagmitter stammer fra Dongge Cave i det sydlige Kina samt Qunf Cave i Oman, og de muliggør en rekonstruktion af nedbørsmængderne gennem de sidste ca. 10 tusinde år i disse områder. De to spektakulære $\delta^{18} \mathrm{O}$-datasæt fra Kina og Oman er meget veldaterede og kan sammenlignes med data fra grønlandske iskerner, hvad angår opløselighed i tid.

\section{Jordens magnetfelt og tropisk nedbør} En sammenligning mellem rekonstruktionen af Jordens dipolmoment og de to $\delta^{18} \mathrm{O}$-datasæt fra hhv. Dongge Cave i Kina og Qunf Cave i Oman kan give et fingerpeg om, hvorvidt Jordens magnetfelt faktisk har påvirket klimaet gennem Holocæn. For at sammenligne æbler med æbler og pærer med pærer grupperede vi de to $\delta^{18} \mathrm{O}$-datasæt i tidsvinduer svarende til dem, der er brugt til at bestemme Jordens dipolmoment. Denne første sammenligning viser, at der er en meget god korrelation mellem dipolmomentet og mængden af nedbør rekonstrueret fra Dongge Cave over de sidste $\sim 6.000$ år (figur A øverst i ovenstående illustration).

For at få et mere detaljeret indblik i sammenhængen mellem dipolmomentet og nedbørsmængderne gennemførte vi samme simple sammenligning, men nu baseret på en gruppering af magnetiske og $\delta^{18} \mathrm{O}$-data $i$ kortere tidsvinduer (100 år). Denne sammenligning viser stadig en utroligt god korrelation mellem de højfrekvente svingninger i dipolmomentet og nedbørsmængderne rekonstrueret fra Dongge Cave (figur B nederst $\mathrm{i}$ ovenstående illustration).

Det er almindeligt accepteret, at ændringer i Jordens baneparameter (orientering og hældning af Jordens rotationsakse samt formen af Jordens bane omkring Solen) har styret de langbølgede ændringer i monsunnedbøren i de tropiske egne. Dette skyldes hovedsageligt, at Jordens aksehældning påvirker positionen af den intertropiske konvergenszone (ITCZ), (den intertropiske konvergenszone er et lavtryksbælte, der omkranser Jorden tæt ved ækvator. Her mødes (konvergerer) varme og fugtige luftmasser fra nord med luftmasser fra syd), som er udslagsgivende for fordelingen af nedbør i tropiske egne.

Som det fremgår af figurerne ovenfor, er der en meget god korrelation mellem ændringer i solindstrålingen ved $30^{\circ} \mathrm{N}$ forårsaget af ændringer i Jordens baneparameter og monsun-nedbøren i Kina og Oman. Da det også er blevet foreslået, at ændringer i Jordens baneparameter påvirker dannelsen af magnetfeltet i den flydende ydre kerne, er det naturligt at korrigere både Jordens dipolmoment og nedbørsmængderne for denne effekt.

Efter at have korrigeret for de langbølgede effekter af Jordens baneparameter observerer vi stadig en meget god korrelation mellem ændringer i Jordens dipolmoment og $\delta^{18} \mathrm{O}$-data fra Dongge Cave - både for sammenligningen baseret på en kombination af 500- og 1.000-års tidsvinduer og den baseret på 100-års vinduer (figuren øverst på næste side). Korrelationen mellem dipolmomentet og $\delta^{18} \mathrm{O}$-data fra Qunf Cave i Oman er god i visse perioder over de sidste 6.000 år (ikke vist), men generelt er den ikke så åbenlys som i tilfældet med Dongge Cave. Begge rekonstruktioner fra hhv. Kina og Oman viser, at mængden af nedbør steg betragteligt over de sidste $\sim 1.500$ år, hvilket 
korrelerer næsten perfekt med et fald i dipolmomentet i denne periode.

Sammenligningerne viser altså, at der er en meget god korrelation mellem Jordens dipolmoment og de rekonstruerede nedbørsmængder i det sydlige Kina, hvilket netop er et af de steder, hvor man ville forvente at finde sporene af en sådan forbindelse ud fra betragtninger om bl.a. magnetfeltets geometri. Da de palæomagnetiske data, som rekonstruktionen af Jordens dipolmoment hviler på, ikke påvirkes af ændringer i klimaet, betyder dette resultat, at Jordens magnetfelt sandsynligvis har influeret på mængden af nedbør i visse områder tæt ved ækvator.

Det er umuligt ud fra dette studium at kvantificere eller vurdere den geografiske udstrækning af denne effekt. Det er således sandsynligt, at Jordens magnetfelt har påvirket nedbørsmængderne i det sydlige Kina $i$ højere grad end i Oman, og at nedbørsmængderne i områder fjernt fra den geomagnetiske ækvator ikke har været påvirket af Jordens dipolmoment i nævneværdig grad. Dette stemmer fint overnes med et studium fra 2006, der viste, at ioniseringen i atmosfæren forårsaget af ændringer i Jordens magnetfelt kan variere betragteligt over relativt korte afstande.

Konklusionen på dette studium er derfor, at flere faktorer har påvirket mængden af nedbør i tropiske egne gennem den holocæne periode. De langbølgede ændringer i nedbøren har hovedsageligt været styret af ændringer i Jordens baneparameter, mens
Monsun-nedbøren og Jordens dipolmoment

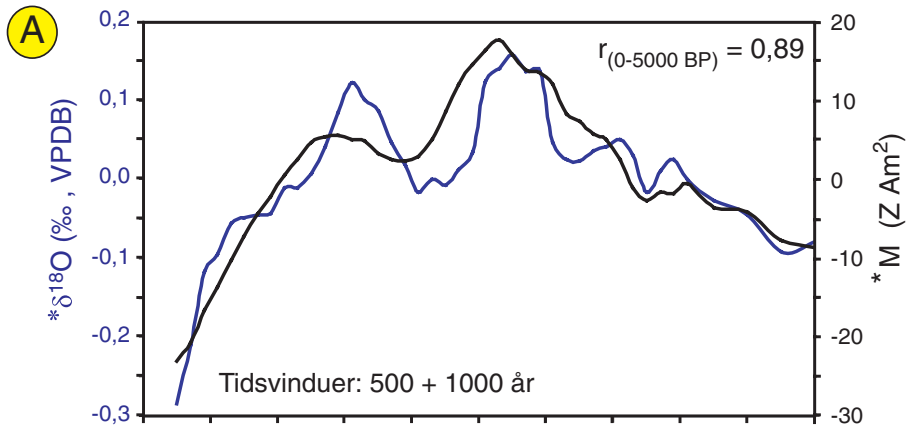

(B)

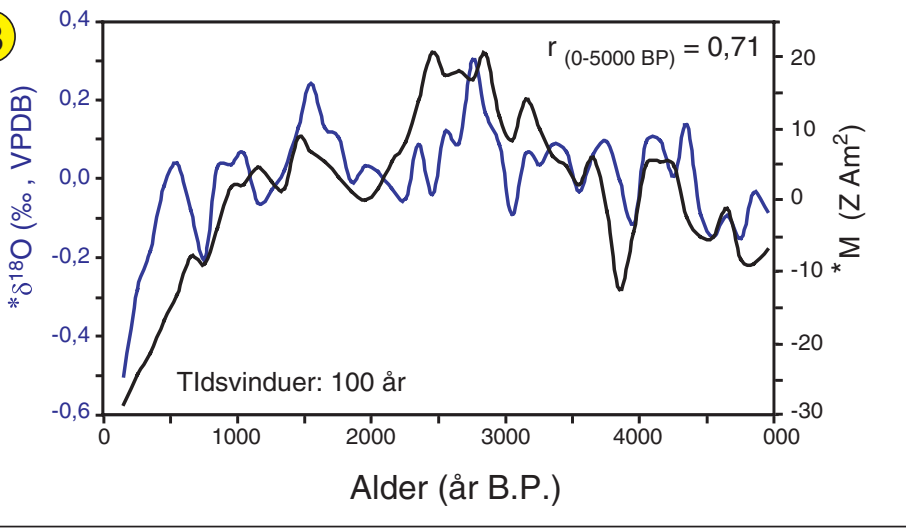

Jordens dipolmoment (sort) og $\delta^{18} O$-data (blå) fra drypstenshulen Dongge Cave $i$ det sydlige Kina. I denne figur er cendringer $i$ Jordens dipolmoment samt de pågceldende $\delta^{18} O$-data blevet korrigeret for cendringer $i$ Jordens baneparameter (orange kurve i figuren på foregående side). Figuren viser en rekonstruktion af Jordens dipolmoment og nedbørsmangder $i$ det sydlige Kina baseret på en gruppering af data i tidsintervaller med forskellig longde: (A) en kombination af 500- og 1000-års vinduer og (B) 100-års vinduer. (Grafik: Forfatterne)

\section{Jordens Dipolmoment}

I år 1600 skrev Dr. William Gilbert "De Magnete" (On the Magnet), der anses som den første egentlige eksperimentalvidenskabelige afhandling. I "De Magnete" konkluderer Gilbert: "magnus magnes ipse est globus terrestris" (Jordkuglen er i sig selv en stor magnet), og han havde ganske ret: Jordens magnetfelt kan faktisk tilnærmelsesvis beskrives som feltet fra en kæmpestor dipol-magnet placeret i Jordens centrum parallelt med omdrejningsaksen. Styrken af en dipol-magnet beskrives bedst via termen "dipolmoment", og derfor beskriver man i palæomagnetiske undersøgelser ofte styrken af Jordens tidligere magnetfelt ved "Jordens dipolmoment".

Skitsen til venstre viser Terrella (lille Jord), som William Gilbert brugte, da han skulle demonstrere Jordens magnetfelt for Dronning Elizabeth I. Til højre ses en lidt mere moderne opfattelse af Jordens magnetfelt, baseret på

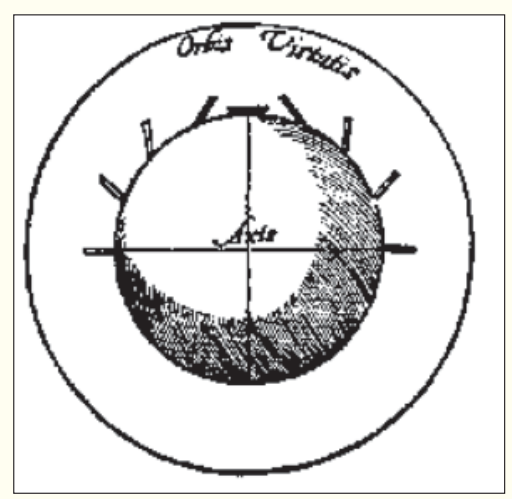

Gilbert, W. (1600). De Magnete - "On the Magnet". Chiswick Press,London.

computer-simuleringer af magnetfeltlinier, der dannes $i$ Jordens flydende ydre kerne (fra Gary Glatzmaier, University of California, Santa Cruz). De blå linier angiver feltlinier, der er indadrettet, mens orange feltlinier er udadrettede.

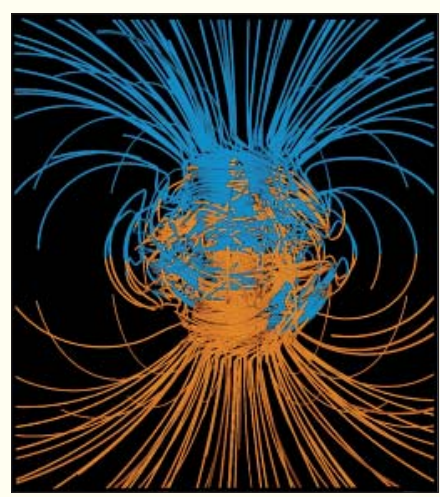

Glatzmaier, G.A., R.S. Coe, L. Hongre, PH. Roberts (1999) The role of the Earth's mantle in controlling the freqency of geomagnetic reversals. Nature 401, 885-890.

Ved kerne-kappe-grcensen sker der et meget markant skift i feltstrukturen, som overgår fra en yderst kompleks struktur til den mere simple, dipol-agtige struktur, som vi kan observere ved Jordens overflade. 
de kortbølgede ændringer har været styret af fluktuationer i Jordens dipolmoment, ændringer i Solens aktivitet, samt ændringer $i$ atmosfæriske cirkulationsmønstre. Interessant er det at bemærke, at stigningen i nedbørsmængder over de sidste $\sim 1.500$ år, der er observeret $i$ både Kina og Oman, bedst kan forklares med en samtidig ændring i Jordens dipolmoment.

\section{Den kausale sammenhæng}

Det er værd at reflektere en smule over den mekanisme, der kan forbinde ændringer i Jordens dipolmoment med nedbørsmængden i troperne. Det mest sandsynlige er, at Jordens magnetfelt har moduleret den mængde af kosmiske partikler, der er trængt ind $i$ atmosfæren og derved skyernes mikrofysiske processer. Vores studium viser, at et fald i dipolmomentet har været forbundet med en stigning i nedbørsmængden, hvilket faktisk er det modsatte af, hvad man skulle forvente. Hvis dipolmomentet falder, og flere kosmiske partikler kan trænge ind $i$ atmosfæren og derved danne flere lave skyer, vil der være mindre energi tilgængelig til fordampning, og man ville derfor forvente et fald i nedbøren.

Koncentrationen af aerosoler i atmosfæren påvirker imidlertid skyernes mikrofysik og "tilbøjelighed" til at regne og flere studier har vist, at en stigning i koncentrationen af aerosoler kan føre til, at skyerne har en tendens til at holde på vandet. Dette kan medføre, at vandmængden i skyerne stiger, og at nedbøren på denne måde bliver forøget, når vandet regner ud på et senere tidspunkt i skyens livscyklus. Sådan en proces kunne potentielt forklare den sammenhæng, vi har observeret mellem ændringer i dipolmomentet og nedbøren i tropiske områder.

Faktum er dog, at vi på nuværende tidspunkt ikke ved nok om forbindelsen mellem ioner i atmosfæren, aerosoler, skydannelse og nedbør til at forstå den mekanisme, der kan forbinde Jordens magnetfelt med ændringer i nedbøren.

\section{Afsluttende overvejelser}

Med afsæt i vore undersøgelser og resultater foreslår vi altså, at Jordens magnetfelt har påvirket klimaet gennem den holocæne periode. Vores postulat understøttes dels af de fysiske modeller, der sandsynliggør, hvorledes magnetfeltet kan påvirke klimaet, dels af data der viser en korrelationen mellem Jordens dipolmoment og ændringer i tropiske nedbørsmængder.

Hvis man godt kan lide statistik, kan man udregne, at sandsynligheden er forsvindende lille, for at korrelationen mellem nedbør og magnetfelt (figuren på side 6) er resultatet af to uafhængige parametre, der tilfældigvis har varieret på samme måde. Vi mener, at dette resultat er vigtigt, fordi det leverer de hidtil stærkeste indicier for, at Jordens magnetfelt faktisk har påvirket klimaet. Dette betyder på ingen måde, at Jordens magnetfelt har spillet en væsentlig rolle for udviklingen af Jordens klima som helhed, men det er med til at nuancere vores forståelse af kompleksiteten af Jordens klimasystem.

Som altid er det vigtigt at bibeholde sin kritiske/selvkritiske sans. Eftersom magnetfelt-klima-sammenhængen er en ekstraordinær hypotese, bør man måske endda være ekstraordinært kritisk. I denne forbindelse er det vigtigt at huske på, at en god korrelation ikke er ensbetydende med kausalitet. Korrelationen giver kun mening, hvis den teoretiske baggrund er valid. Der er uden tvivl brug for en bedre fysisk forståelse af de fundamentale processer, hvorved magnetfeltet kan påvirke Jordens klima. Desuden bygger vores analyser på data fra to stalagmitter, hvilket repræsenterer et spinkelt og ufuldstændigt grundlag. Problemet er bare, at det på nuværende tidspunkt ikke er muligt at udvide undersøgelsen, fordi arkivet over tropiske nedbørsmængder gennem Holocæn er mangelfuldt.

Heldigvis er magnetfelt-klima-hypotesen i overensstemmelse med Karl Poppers ånd ${ }^{1)}$, idet den er falsificerbar. Det, der er brug for, hører fremtiden til, nemlig flere palæomagnetiske undersøgelser samt flere klimadata, heriblandt $\delta^{18} \mathrm{O}$-data fra stalagmitter, som vil kunne belyse sammenhængen mellem Jordens magnetfelt og klimasystemet.

${ }^{1)}$ Ifølge den østrigsk-fødte videnskabsfilosof Karl Raimund Popper kan en teori kun karakteriseres som videnskabelig hvis den er falsificerbar - dvs. at teorien skal vare udformet på en sådan måde, at der kan opstilles forsøg, der potentielt kan modbevise den.

Links og anbefalet videnskabelig litteratur:

GEOMAGIA50: http://geomagia.ucsd.edu/

Fleitmann, D., et al. (2003). Holocene forcing of the Indian Monsoon recorded in a stalagmite from Southern Oman. Science 300, 1737-1739.

Hu, C., G.M. Henderson, J. Huang, S. Xie, Y. Sun, K.R. Johnson (2008). Quantification of Holocene Asian monsoon rainfall from spatially separated cave records. Earth and Planetary Science Letters 266, 221-232.

Knudsen, M.F. \& P. Riisager (2009). Is there a link between Earth's magnetic field and low-latitude precipitation? Geology 37, 71-74.

Knudsen, M.F., P. Riisager, F. Donadini, I. Snowball, R. Muscheler, K. Korhonen, L.J. Pesonen (2008). Variations in the geomagnetic dipole moment during the Holocene and the past $50 \mathrm{kyr}$. Earth and Planetary Science Letters 272, 319-329.

Usoskin, I.G., M. Korte, and G.A. Kovaltsov (2008). Role of centennial geomagnetic changes in local atmospheric ionization. Geophisical Research Letters 35, L05811, doi:10.1029/2007GL033040.

Wang, Y., et al. (2005). The Holocene Asian Monsoon: Links to solar changes and North Atlantic climate. Science 308, 854-857.

\section{Kort nyt}

\section{Jordskælv ved Java}

Mindst 32 mennesker blev dræbt og 5.000 drevet på flugt, da et kraftigt jordskælv 2 . september ramte Indonesiens hovedø, Java. Mange bygninger i hovedstaden Jakarta rystede, mens andre tættere på epicentret styrtede sammen. Myndighederne meldte om ødelæggelser i Tasikmalaya i nærheden af skælvets epicenter ud for den vestlige del af Java. USA's Geologiske Undersøgelser (USGS) målte skælvet til 7,0 på Richterskalaen.

\section{$J P / S L J$}

\section{Jordskælv i Bhutan}

Det lille kongedømme Bhutan i Himalaya blev 21. september ramt af et jordskælv, der blev målt til 6,3 på Richterskalaen. Mindst syv mennesker mistede livet som følge af jordskælvet. Skælvet anrettede også betydelig skade på klostre og andre bygninger. Ifølge USA's Geologiske Undersøgelser lå epicenteret tæt på Bhutans grænse til Indien.

$J P / S L J$ 